\title{
Radio-adaptive Response: An Implication for the Biological Consequences of Low Dose-rate Exposure to X-Ray
}

\author{
A. A. Fahmy, A. S. El-Said, M. H. Shabon*, M. M. Ahmed** \\ and Z. S. Said* \\ Chemistry Dept., Faculty of Science, Cairo University, \\ *Radiation Safety Dept., Nuclear \& Radiological Regulatory \\ Authority and ${ }^{* *}$ Radiation Biology Dept., National Centre for \\ Radiation Research and Technology (NCRRT), P. O. Box; 29 \\ Nasr City, Egypt.
}
R ADIATION induced adaptive response is described as the reduced damaging effect of a challenging radiation dose when induced by a previous low priming dose. To verify the radio-adaptive response that can be induced by occupationally (in vivo) received chronic low dose of $\mathrm{X}$-ray, chromosomal aberration (CA) analysis, micronucleus test (MN), interleukin- $1 \beta$ (IL-1 $\beta)$ and nitric oxide (NO) concentrations were investigated for both the occupationally exposed and control groups before and after exposure to $2 \mathrm{~Gy} \gamma$-rays as a challenge dose.
The results showed that an elevated frequency of CA, MN and nucleoplasmic bridge (NPB) was recorded in radiation workers (exposed group) compared to control group. However, after $2 \mathrm{~Gy}$ in vitro irradiation of lymphocytes of exposed and control groups, the exposed group was found to be lower than that of control group.
On the other hand, IL-1 $\beta$ and NO concentrations in plasma were elevated in exposed group more than in control group. While, after $2 \mathrm{~Gy}$ irradiation for both groups, there are higher increment in the concentrations of IL-1 $\beta$ and NO in exposed group than the increment difference observed for control group after in vitro irradiation as compared to the same group before irradiation.
The present results suggested the existence of an in vivo cytogenetic adaptive response in individuals occupationally exposed to low dose of X-ray. In addition, the results showed that NO radicals and IL- $1 \beta$ have a role in the induction of radio-resistance due to in vivo exposure that may intermediate this radiation.

Keywords: Adaptive response, occupation exposure, x-ray, chromosome aberration, IL-1 $\beta$, nitric oxide. 
There is much debate concerning the biological effects of low dose ionizing radiation and whether a threshold dose exists for such effects. The International Commission on Radiological Protection (ICRP) (ICRP, 1990) has adopted the so-called "linear-no threshold" (LNT) hypothesis to estimate the risks for the stochastic effects of ionizing radiation. Under this hypothesis, the biological effect is assumed to be proportional to the radiation dose received, with no dose threshold for such effects. Hence the ICRP adopted a cautious approach in the light of scientific knowledge at that time and subsequently many national regulatory bodies have based their radiation exposure dose limits for occupationally exposed workers and members of the public on risk estimates derived using this model. However, there have been relatively few data obtained at low doses to support such an important concept (Goldberg et al., 2004 and Prasad et al., 2004).

X-ray machines and radiation emitting sources are used in hospitals for the diagnosis and treatment of diseases. Some of the hospital employees who work in radiology, nuclear medicine, radiation oncology, and some laboratories are specifically trained in the operation of radiation machines and the handling of radioactive materials and sources. Health risks from radiation exposure in such a large occupational segment of the population are clearly of special concern (AAPM report, 1995).

Radiation-induced adaptive response is described as the reduced damaging effect of a challenging radiation dose when induced by a previous low priming dose. Adaptive responses have been observed in vitro and in vivo using various indicators of cellular damage, such as cell lethality, CAs, mutation induction, radiosensitivity, and DNA repair. In addition, there is general acceptance that mammalian cells carry out repair and control of DNA injury by constitutive processes, that remain available to cope with background damage to DNA, replication and housekeeping, and also by pathways that may be upregulated or induced in response to excessive injury which demands more aggressive repair to retain cell viability (Wolff et al., 1989).

Bio-dosimeter, the biological assessment of radiation dose in individuals through the measure of specific dose-associated effects, provides a measure of the absorbed dose taking into account the individual radiation sensitivity. Cytogenetic biomarkers have been used in occupational setting for over 50 years, especially in the field of radioprotection, where the frequency of CA is currently used as a biological dosimeter of ionizing radiation (Ropolo et al., 
2012). On the other hand, there are new investigation methods that allow cytokines to be used as radioprotective or radiosensitizing agents. They can also be used to minimize the effects of irradiation indirectly by neutralizing other harmful cytokines. Evidence from both the laboratory and the clinic indicates a promising future for these molecules as modulators for the radiation response (Laiakis et al., 2007). Several researches have studied the radioprotective effects of IL-1 and tumour necrosis factor (TNF- $\alpha$ ) confer radioresistance by promoting repair and restoring the host defenses (Neta et al., 1991). IL-1 $\beta$ has been hypothesized to induce hematopoietic growth factors and endogenous antioxidant mechanisms such as metallothionein, cerruloplasmin, and MnSOD (Weiss and Landauer, 2000). NO is an important cellular signaling molecule that is involved in a variety of signal transduction pathways and possesses unique physiologic or pathologic properties, which have been described as cytoprotective, cytostatic, pro-apoptotic, or anti-apoptotic. NO also plays an important role in the regulation of tumour evolution (Brune, 2003, Li and Wogan, 2005 and Xu et al., 2002).

Our study aimed to examine the influence of low dose rate of X-ray on the occupationally exposed persons and the health risk in view of the adaptive response theory.

\section{Materials and Methods}

\section{Subjects}

Ten individuals ( 6 physician and 4 technicians) had been occupationally exposed to low levels of radiation during their handling with X-ray machine; Shimadzu Corporation, Voltage: 125 V, Current: 450 m.A. During radiography with fixed installations, the radiographer would normally be expected to stand in a control booth that is typically shielded as a secondary barrier against X-ray tube leakage and scattered radiation. None of the workers was exposed to whole body doses of ionizing radiation beyond the annual limit of $20 \mathrm{mSv}$. Their mean exposure was $0.24 \mathrm{mSv}(0-4.66 \mathrm{mSv})$ during the previous year of blood collection. The reference control group consisted of 10 individuals with no history of exposure to ionizing radiation or chemical compounds. All the subjects of both groups lived in the same urban area.

\section{Subject questionnaire}

All the participants were informed about the aim of the study prior to blood collection in the course of a routine occupational medical examination by a specialized physician who filled in a structured questionnaire which covered 
standard demographic questions, as well as an occupational, medical and family history. For the organization of the data analysis, each variable was assigned to one of the following categories: demographics, life style, work exposure and medical history.

\section{Blood sampling}

Samples of $5 \mathrm{ml}$ of whole blood were collected in heparinized vacationer tubes under sterile conditions by vein puncture in the morning h, between 9 and $10 \mathrm{am}$, after collection, all blood samples were randomly coded, cooled to $4{ }^{0} \mathrm{C}$ and transported to the laboratory. Processing and scoring of samples of the 2 groups were then performed blind and concurrently in the laboratory (usually within $2 \mathrm{~h}$ following the sampling). Each peripheral blood sample was divided into two main categories; one as the control (before irradiation) and the other for in vitro exposure to 2 Gy $\gamma$-rays. Each part was then subdivided into two parts; one was used for MN and CA assay and the other for biochemical analysis.

\section{Irradiation protocol}

Heparinized blood samples were exposed to a single dose of 2 Gy at dose rate of $0.492 \mathrm{~Gy} / \mathrm{min}$. Irradiation was carried out using the Canadian Gamma Cell-40 biological irradiation belonging to the National Center for Radiation Research and Technology (NCRRT) Cairo, Egypt.

\section{The analysis of structural chromosome aberrations \& micronucleus test}

The structural CA was performed according to current IAEA guidelines (IAEA, 2001). Four separate culture vials were set up from each individual; 2 for the control (MN \& CA) and the other 2 exposed to 2 Gy $\gamma$-rays (MN \& CA). A short-term culture of lymphocytes for $\mathrm{CA}$ and $\mathrm{MN}$ was set up.

The MN assay was performed as described by fenech (1993) with some modifications, Fenech (2000).

\section{Biochemical analysis}

Blood samples were collected in dry clean centrifuge tubes that contained heparin to obtain plasma and then centrifuged at $2000 \mathrm{rpm}$ for $10 \mathrm{~min}$ and the resulting supernatant plasma was collected. Plasma samples were used for the following analysis; IL-1 $\beta$ was determined in plasma according to the method described by Orgenium Laboratories procedure (IL-1 $\beta$ ELISA kit). All reagents

Egypt. J. Rad. Sci. Applic., Vol. 27, No. 1-2 (2014) 
used were purchased from AviBion Human IL-1 $\beta$ ELISA. NO was determined in plasma according to the method described by Miranda et al. (2001).

\section{Statistical analysis}

Statistical analyses were performed using analysis of variance (ANOVA) according to (Snedecor and Cochran, 1980). Data were presented as mean \pm S.E. and $P \leq 0.05$ was considered statistically significant.

\section{Results}

\section{The personal data of the subjects}

As shown in Table 1. the data of exposed group comprises 5 males and 5 females, these persons had been occupationally exposed to X-ray with mean duration of 18.6 years. The mean age of this exposed group was 40.9 years (range 28-52 years). The subjects of control group matched the exposed subjects in age and smoking habits.

TABLE 1. A) Personal data of exposed group.

\begin{tabular}{|c|c|c|c|c|c|c|c|c|c|c|}
\hline \multicolumn{11}{|c|}{ A) Exposed } \\
\hline \multirow{2}{*}{$\begin{array}{c}\text { Indiv. } \\
\text { No. }\end{array}$} & \multirow{2}{*}{$\operatorname{Sex}$} & \multirow[b]{2}{*}{ Age } & \multirow[b]{2}{*}{ Occup. } & \multirow[b]{2}{*}{ Rad. } & \multicolumn{2}{|c|}{ Duration } & \multicolumn{3}{|c|}{ Medical history } & \multirow{2}{*}{$\begin{array}{l}\text { Smok. } \\
\text { Status }\end{array}$} \\
\hline & & & & & $\begin{array}{l}\text { No. of } \\
\text { years }\end{array}$ & $\begin{array}{l}\text { No. of } \\
\text { h/day }\end{array}$ & Disease & Drug & $\begin{array}{c}\text { X-ray } \\
\text { exposure }\end{array}$ & \\
\hline 1 & $* \mathrm{~F}$ & 38 & Techn. & X-ray & 18 & 6 & $==$ & $==$ & $==$ & *NS \\
\hline 2 & $\mathrm{~F}$ & 35 & Techn. & X-ray & 15 & 6 & Anaemia & $==$ & $==$ & NS \\
\hline 3 & $\mathrm{~F}$ & 35 & Techn. & X-ray & 15 & 6 & $==$ & $==$ & $==$ & NS \\
\hline 4 & $* \mathrm{M}$ & 52 & Physic. & X-ray & 26 & 6 & $==$ & $==$ & $==$ & ${ }^{*} \mathrm{~S}$ \\
\hline 5 & $\mathrm{M}$ & 40 & Physic. & X-ray & 18 & 6 & $==$ & $==$ & $==$ & NS \\
\hline 6 & $\mathrm{~F}$ & 48 & Physic. & X-ray & 25 & 6 & $==$ & $==$ & $==$ & NS \\
\hline 7 & M & 45 & Physic. & X-ray & 23 & 6 & $==$ & $==$ & $==$ & $\mathrm{S}$ \\
\hline 8 & $\mathrm{M}$ & 39 & Techn. & X-ray & 16 & 6 & $==$ & $==$ & $==$ & NS \\
\hline 9 & $\mathrm{~F}$ & 49 & Physic. & X-ray & 24 & 6 & $==$ & Vitamin & $==$ & NS \\
\hline 10 & $\mathrm{M}$ & 28 & Physic. & X-ray & 6 & 6 & $==$ & $==$ & $==$ & $S$ \\
\hline
\end{tabular}

All subjects of exposed and control groups were not under any prescription or non-prescription medications, vaccinations, and X-ray or another diagnostic proof within the last year before blood sampling. Only one subject (No.9) in exposed group and subject (No.1) in control group received a course of natural vitamins through the last three months.

Egypt. J. Rad. Sci. Applic., Vol. 27, No. 1-2 (2014) 
TABLE 1. B) Personal data of control group.

\begin{tabular}{|c|c|c|c|c|c|c|c|c|c|c|}
\hline \multicolumn{11}{|c|}{ B) Control } \\
\hline \multirow[b]{2}{*}{$\begin{array}{c}\text { Indiv. } \\
\text { No. }\end{array}$} & \multirow[b]{2}{*}{ Sex } & \multirow[b]{2}{*}{ Age } & \multirow[b]{2}{*}{ Occup. } & \multirow[b]{2}{*}{ Rad. } & \multicolumn{2}{|c|}{ Duration } & \multicolumn{3}{|c|}{ Medical history } & \multirow[b]{2}{*}{$\begin{array}{l}\text { Smok. } \\
\text { Status }\end{array}$} \\
\hline & & & & & $\begin{array}{l}\text { No. of } \\
\text { years }\end{array}$ & $\begin{array}{l}\text { No. of } \\
\text { h/day }\end{array}$ & Disease & Drug & $\begin{array}{c}\text { X-ray } \\
\text { exposure }\end{array}$ & \\
\hline 1 & $* \mathrm{M}$ & 24 & Chemist & $==$ & $==$ & $==$ & $==$ & Vitamin & $==$ & NS \\
\hline 2 & $\mathrm{M}$ & 40 & Chemist & $==$ & $==$ & $==$ & $==$ & $==$ & $==$ & * $\mathrm{S}$ \\
\hline 3 & $* \mathrm{~F}$ & 32 & Employee & $==$ & $==$ & $==$ & $==$ & $==$ & $==$ & NS \\
\hline 4 & $\mathrm{M}$ & 28 & Employee & $==$ & $==$ & $==$ & $==$ & $==$ & $==$ & NS \\
\hline 5 & $\mathrm{M}$ & 49 & Engineer & $==$ & $==$ & $==$ & $==$ & $==$ & $==$ & $\mathrm{S}$ \\
\hline 6 & $\mathrm{M}$ & 34 & Employee & $==$ & $==$ & $==$ & $==$ & $==$ & $==$ & NS \\
\hline 7 & $\mathrm{~F}$ & 26 & Employee & $==$ & $==$ & $==$ & $==$ & $==$ & $==$ & NS \\
\hline 8 & $\mathrm{~F}$ & 29 & Employee & $==$ & $==$ & $==$ & $==$ & $==$ & $==$ & NS \\
\hline 9 & $\mathrm{M}$ & 55 & Engineer & $==$ & $==$ & $==$ & $==$ & $==$ & $==$ & $\mathrm{S}$ \\
\hline 10 & $\mathrm{~F}$ & 34 & Engineer & $==$ & $==$ & $==$ & $==$ & $==$ & $==$ & NS \\
\hline
\end{tabular}

Chromosome aberration analysis of exposed and control groups before and after exposure to $2 \mathrm{~Gy} \gamma$-rays as challenging dose.

Table 2. indicates the mean and standard error of the CA per individual in exposed group before and after irradiation. It reveals that there is a significant increase in chromosome fragments, breaks, dicentrics and total CA after irradiation in comparison with those before irradiation.

The mean value of the total chromosome type aberrations after irradiation was almost 2.4 folds as high as the total chromosome types before irradiation. The frequency of polyploidy and total aberrations revealed a significant increase after irradiation compared to those before irradiation.

The probability values of significance between the means of the different types of aberrations before and after $2 \mathrm{~Gy}$ gamma radiation exposures in control group are presented in Table 2. There is a significant increase in chromosome fragments, breaks, dicentrics and total CA in the control group after irradiation when compared with the same group before irradiation. Similarly, a significant increase in chromatid fragments and total chromatid aberrations was observed in the control group after irradiation compared with the same group before irradiation.

Egypt. J. Rad. Sci. Applic., Vol. 27, No. 1-2 (2014) 
TABLE 2. Probability values of chromosome and chromatid aberration frequencies in exposed and control groups before and after exposure to $2 \mathrm{~Gy} \gamma$-rays.

\begin{tabular}{|l|c|c|c|c|}
\hline $\begin{array}{c}\text { Types of } \\
\text { aberrations }\end{array}$ & $\begin{array}{c}\text { Exposed gp. } \\
\text { before } \boldsymbol{\gamma} \text {-rays }\end{array}$ & $\begin{array}{c}\text { Exposed gp. } \\
\text { after } \boldsymbol{\gamma} \text {-rays }\end{array}$ & $\begin{array}{c}\text { Control gp. } \\
\text { before } \boldsymbol{\gamma} \text {-rays }\end{array}$ & $\begin{array}{c}\text { Control gp. } \\
\text { after } \boldsymbol{\gamma} \text {-rays }\end{array}$ \\
\hline Chs. Frg. & $2.3 \pm 0.37$ & $4.0 \pm 0.39^{\mathrm{b}}$ & $1.6 \pm 0.31$ & $4.7 \pm 0.42^{\mathrm{a}}$ \\
\hline Chs. Brk. & $1.7 \pm 0.30$ & $3.3 \pm 0.47^{\mathrm{b}}$ & $0.8 \pm 0.25$ & $4.7 \pm 0.30^{\mathrm{a}}$ \\
\hline Dicentric & $0.0 \pm 0.00$ & $1.1 \pm 0.35^{\mathrm{b}}$ & $0.0 \pm 0.00$ & $1.7 \pm 0.30^{\mathrm{a}}$ \\
\hline Ring & $0.0 \pm 0.00$ & $0.2 \pm 0.13$ & $0.0 \pm 0.00$ & $0.3 \pm 0.15$ \\
\hline Total Chs. Ab. & $4.3 \pm 0.67$ & $10.4 \pm 1.17^{\mathrm{b}}$ & $2.5 \pm 0.52$ & $13.9 \pm 1.15^{\mathrm{a}}$ \\
\hline Chd. Frg. & $1.5 \pm 0.34$ & $2.1 \pm 0.28$ & $1.2 \pm 0.33$ & $3.1 \pm 0.23^{\mathrm{a}}$ \\
\hline Chd. Brk. & $0.6 \pm 0.22$ & $1.0 \pm 0.26$ & $0.6 \pm 0.34$ & $1.4 \pm 0.48$ \\
\hline Chd.exchange & $0.1 \pm 0.10$ & $0.1 \pm 0.10$ & $0.0 \pm 0.00$ & $0.2 \pm 0.13$ \\
\hline Total Chd. Ab. & $2.2 \pm 0.51$ & $3.2 \pm 0.407$ & $1.8 \pm 0.55$ & $4.7 \pm 0.54^{\mathrm{a}}$ \\
\hline Polyp. & $0.2 \pm 0.13$ & $1.2 \pm 0.20^{\mathrm{b}}$ & $0.0 \pm 0.00$ & $1.3 \pm 0.30^{\mathrm{a}}$ \\
\hline Total Ab. & $6.7 \pm 1.21$ & $14.8 \pm 1.45^{\mathrm{b}}$ & $4.3 \pm 1.02$ & $19.9 \pm 1.70^{\mathrm{a}}$ \\
\hline
\end{tabular}

Gp.: group, Chs: Chromosome, Chd: Chromatid, Frg: Feagment, Brk: Break, Ab: Aberration. Polp: Polyploidy, ${ }^{\text {a }}$ : Significantly different from control group before irradiation, ${ }^{\mathbf{b}}$ : Significantly different from exposed group before irradiation, Data (Mean \pm S.E.) are considered significant at $P<0.05, \mathrm{n}=10$.

Table 3. shows that the statistical differences between the means of chromosome fragments, chromatid fragments, chromatid breaks, chromatid exchanges, total chromatid aberrations, polyploidy and total aberrations were insignificantly increased, before $\gamma$-rays, in the exposed group when compared with control group. Whereas, the differences between the means of chromosome breaks and total CA were significant $(P<0.05)$ before $\gamma$-rays in the exposed group as compared with control group.

TABLE 3. Probability values of chromosome and chromatid aberration frequencies in exposed and control groups before exposure to $2 \mathrm{~Gy} \gamma$-rays.

\begin{tabular}{|l|c|c|}
\hline Types of aberrations & Control group before $\boldsymbol{\gamma}$-rays & Exposed group before $\boldsymbol{\gamma}$-rays \\
\hline Chs. Frg. & $1.6 \pm 0.31$ & $2.3 \pm 0.37$ \\
\hline Chs. Brk. & $0.8 \pm 0.25$ & $1.7 \pm 0.3^{\mathrm{a}}$ \\
\hline Dicentric & $0.0 \pm 0.00$ & $0.0 \pm 0.00$ \\
\hline Ring & $0.0 \pm 0.00$ & $0.0 \pm 0.00$ \\
\hline Total Chs. Ab. & $2.5 \pm 0.52$ & $4.3 \pm 0.67^{\mathrm{a}}$ \\
\hline Chd. Frg. & $1.2 \pm 0.33$ & $1.5 \pm 0.34$ \\
\hline Chd. Brk. & $0.6 \pm 0.34$ & $0.6 \pm 0.22$ \\
\hline Chd.exchange & $0.0 \pm 0.00$ & $0.1 \pm 0.1$ \\
\hline Total Chd. Ab. & $1.8 \pm 0.55$ & $2.2 \pm 0.51$ \\
\hline Polyp. & $0.0 \pm 0.00$ & $0.2 \pm 0.13$ \\
\hline Total Ab. & $4.3 \pm 1.02$ & $6.7 \pm 1.21$ \\
\hline \multicolumn{2}{|c|}{} \\
\hline
\end{tabular}

Legend as in Table 2 .

Egypt. J. Rad. Sci. Applic., Vol. 27, No. 1-2 (2014) 
The results in Table 4. reveals that a significant decrease in chromosome breaks, total CA, chromatid fragments, total chromatid aberrations and total aberrations were recorded after irradiation in the exposed group when compared to those of control group. On the other hand, this decrease was found to be insignificant in chromosome fragments, dicentrics, rings, chromatid breaks, chromatid exchanges and polyploidy in exposed group when compared to those of control group.

TABLE 4. Probability values of chromosome and chromatid aberration frequencies in exposed and control groups after exposure to $2 \mathrm{~Gy} \gamma$-rays.

\begin{tabular}{|l|c|c|}
\hline Types of aberrations & Control group before $\boldsymbol{\gamma}$-rays & Exposed group before $\boldsymbol{\gamma}$-rays \\
\hline Chs. Frg. & $4.7 \pm 0.42$ & $4.0 \pm 0.39$ \\
\hline Chs. Brk. & $4.7 \pm 0.3$ & $3.3 \pm 0.47^{\mathrm{d}}$ \\
\hline Dicentric & $1.7 \pm 0.3$ & $1.1 \pm 0.35$ \\
\hline Ring & $0.3 \pm 0.15$ & $0.2 \pm 0.13$ \\
\hline Total Chs. Ab. & $13.9 \pm 1.15$ & $10.4 \pm 1.1^{\mathrm{d}}$ \\
\hline Chd. Frg. & $3.1 \pm 0.23$ & $2.1 \pm 0.28^{\mathrm{d}}$ \\
\hline Chd. Brk. & $1.4 \pm 0.48$ & $1.0 \pm 0.26$ \\
\hline Chd.exchange & $0.2 \pm 0.13$ & $0.1 \pm 0.1$ \\
\hline Total Chd. Ab. & $4.7 \pm 0.54$ & $3.2 \pm 0.47^{\mathrm{d}}$ \\
\hline Polyp. & $1.3 \pm 0.3$ & $1.2 \pm 0.2$ \\
\hline Total Ab. & $19.9 \pm 1.70$ & $14.8 \pm 1.45^{\mathrm{d}}$ \\
\hline
\end{tabular}

${ }^{\mathrm{d}}$ : Significantly different from control group after irradiation.

Legend as in Table 2.

Micronucleus test of exposed and control groups before and after exposure to 2 Gy $y$-rays as challenging dose

1000 cytokinesis blocked cells were scored (cells which have complete nuclear but not cytoplasmic division) for each individual of the exposed and control groups. Table 5. shows the means, standard errors and probability values of cells with one, two, and three MN in the exposed group before and after irradiation.

A significant increase in the mean values of cells with one, two, and three $\mathrm{MN}$, and total number of $\mathrm{MN}$ was observed in the exposed group after irradiation when compared with those before irradiation. In addition, the probability value of cells with nucleoplasmic bridge in the exposed group after irradiation is statistically significant $(P<0.05)$ when compared with those of the same group before irradiation.

Egypt. J. Rad. Sci. Applic., Vol. 27, No. 1-2 (2014) 
TABLE 5. Means and standard errors of $1,2,3 \mathrm{MN} /$ individual in the exposed and control groups before and after exposure to $2 \mathrm{~Gy} \gamma$-rays as a challenge dose.

\begin{tabular}{|l|c|c|c|c|}
\hline $\begin{array}{c}\text { Means } \pm \text { S.E. } \\
\text { No. of individual }\end{array}$ & $\begin{array}{c}\text { Exposed gp. } \\
\text { before } \boldsymbol{\gamma} \text {-rays }\end{array}$ & $\begin{array}{c}\text { Exposed gp. } \\
\text { after } \boldsymbol{\gamma} \text {-rays }\end{array}$ & $\begin{array}{c}\text { Control gp. } \\
\text { before } \boldsymbol{\gamma} \text {-rays }\end{array}$ & $\begin{array}{c}\text { Control gp. } \\
\text { after } \boldsymbol{\gamma} \text {-rays }\end{array}$ \\
\hline Cell with one MN & $15.8 \pm 0.87$ & $28.6 \pm 1.53^{\mathrm{b}}$ & $11.6 \pm 0.72$ & $35.6 \pm 1.87^{\mathrm{a}}$ \\
\hline Cell with two MN & $0.9 \pm 0.23$ & $2.3 \pm 0.3^{\mathrm{b}}$ & $0.7 \pm 0.21$ & $2.4 \pm 0.34^{\mathrm{a}}$ \\
\hline Cell with three MN & $0.0 \pm 0.00$ & $0.4 \pm 0.16^{\mathrm{b}}$ & $0.0 \pm 0.00$ & $0.4 \pm 0.16^{\mathrm{a}}$ \\
\hline Total no. of MN & $17.6 \pm 1.19$ & $34.4 \pm 2.1^{\mathrm{b}}$ & $13.0 \pm 1.02$ & $41.6 \pm 2.63^{\mathrm{a}}$ \\
\hline No. of NPB & $0.6 \pm 0.31$ & $2.0 \pm 0.47^{\mathrm{b}}$ & $0.3 \pm 0.15$ & $3.6 \pm 0.48^{\mathrm{a}}$ \\
\hline
\end{tabular}

Legend as in Table 2 .

Table 5. shows the frequency of the total number of $\mathrm{MN}$ in the control group after irradiation was increased 3.2 folds compared with those of the control group before $\gamma$-rays. A highly significant increase in the mean values of $1,2,3 \mathrm{MN}$, total number of MN and NPB was observed in the control group after $\gamma$-rays compared to those of the control group before gamma irradiation.

TABLE 6. Means and standard errors of 1, 2, $3 \mathrm{MN} /$ individual in the exposed group and control group before exposure to $2 \mathrm{~Gy} \gamma$-rays as a challenge dose.

\begin{tabular}{|l|c|c|}
\hline $\begin{array}{c}\text { Means } \pm \text { S.E. } \\
\text { No. of individual }\end{array}$ & Control gp. before $\boldsymbol{\gamma}$-rays & Exposed gp. before $\boldsymbol{\gamma}$-rays \\
\hline Cell with one MN & $11.6 \pm 0.72$ & $15.8 \pm 0.87^{\mathrm{a}}$ \\
\hline Cell with two MN & $0.7 \pm 0.21$ & $0.9 \pm 0.233$ \\
\hline Cell with three MN & $0.0 \pm 0.00$ & $0.0 \pm 0.00$ \\
\hline Total no. of MN & $13.0 \pm 1.02$ & $17.6 \pm 1.19^{\mathrm{a}}$ \\
\hline No. of NPB & $0.3 \pm 0.15$ & $0.6 \pm 0.31$ \\
\hline
\end{tabular}

Legend as in Table 2.

Data collected in Table 6. illustrates that, before irradiation, the probability values of cells with one $\mathrm{MN}$ and total number of $\mathrm{MN}$ were significantly increased $(P<0.05)$ in the exposed group as compared to the control group, while, the probability values of cells with two MN and NPB were not significant compared with control group.

It could be seen from Table 7. irradiation of samples caused a significant decline in the probability value of cells with one $\mathrm{MN}$ and total number of $\mathrm{MN}$ in the exposed group than those of the control group. In same concern, the probability value of cells with NPB was significantly decreased in the exposed group than that of the control group after exposure to 2 Gy $\gamma$-rays.

Egypt. J. Rad. Sci. Applic., Vol. 27, No. 1-2 (2014) 
TABLE 7. Means and standard errors of $1,2,3 \mathrm{MN} /$ individual in the exposed group and control group after exposure to $2 \mathrm{~Gy} \gamma$-rays as a challenge dose.

\begin{tabular}{|l|c|c|}
\hline $\begin{array}{c}\text { Means } \pm \text { S.E. } \\
\text { No. of individual }\end{array}$ & Control gp. after $\boldsymbol{\gamma}$-rays & Exposed gp. after $\boldsymbol{\gamma}$-rays \\
\hline Cell with one MN & $35.6 \pm 1.87$ & $28.6 \pm 1.53^{\mathrm{d}}$ \\
\hline Cell with two MN & $2.4 \pm 0.34$ & $2.3 \pm 0.30$ \\
\hline Cell with three MN & $0.4 \pm 0.16$ & $0.4 \pm 0.106$ \\
\hline Total no. of MN & $41.6 \pm 2.63$ & $34.4 \pm 2.10^{\mathrm{d}}$ \\
\hline No. of NPB & $3.6 \pm 0.48$ & $2.0 \pm 0.47^{\mathrm{d}}$ \\
\hline
\end{tabular}

Legend as in Table 4

\section{Biochemical effects}

Table 8. clearly shows that there is a significant increase in the mean values of IL-1 $\beta$ in exposed group before irradiation when compared to those of control group, while, a significant decrease in IL-1 $\beta$ levels was recorded after exposure to $2 \mathrm{~Gy}$ compared to those of control samples. On the other hand, a significant increase in the IL-1 $\beta$ levels was noticed in exposed group after irradiation compared to those of the corresponding groups before irradiation. A similar pattern of a significant increase in the IL- $1 \beta$ concentration was recorded in the control group after irradiation when compared with the same group before irradiation. Also, there is a significant increase in $\mathrm{NO}$ concentrations in plasma of individuals of exposed group compared with those of the control group before irradiation.

TABLE 8. Means and standard errors of IL-1 $(\mathrm{pgm} / \mathrm{ml})$ and NO $(\mu \mathrm{mol} / \mathrm{L})$ in plasma of control and exposed group before and after exposure to 2 Gy $\gamma$-rays as a challenge dose.

\begin{tabular}{|c|c|c|c|c|}
\hline \multirow{2}{*}{ Groups } & \multicolumn{2}{|c|}{ IL-1 $\boldsymbol{\beta}(\mathbf{p g m} / \mathbf{m l})$} & \multicolumn{2}{c|}{ NO $(\boldsymbol{\mu m o l} / \mathbf{L})$} \\
\cline { 2 - 5 } & Before $\boldsymbol{\gamma}$-rays & After $\boldsymbol{\gamma}$-rays & Before $\boldsymbol{\gamma}$-rays & After $\boldsymbol{\gamma}$-rays \\
\hline Control group & $3.1 \pm 0.13$ & $25.7 \pm 1.67^{\mathrm{a}}$ & $25.8 \pm 1.39$ & $39.93 \pm 2.24^{\mathrm{a}}$ \\
\hline Exposed group & $3.7 \pm 0.11^{\mathrm{a}}$ & $18.8 \pm 0.38^{\mathrm{bd}}$ & $33.68 \pm 1.49^{\mathrm{a}}$ & $41.99 \pm 1.84^{\mathrm{b}}$ \\
\hline
\end{tabular}

Legend as in Table 4.

This increment was non significant in both exposed group as compared with the control group after irradiation. Meanwhile, NO concentrations were significantly increased in exposed group after irradiation when compared to those of the corresponding groups before irradiation.

\section{Discussion}

The exact risk of radiation-induced cancer at very low doses is not totally understood and is further complicated by many factors, such as the magnitude Egypt. J. Rad. Sci. Applic., Vol. 27, No. 1-2 (2014) 
of the dose, the time span over which the dose was delivered, the general state of the health of the individual, the type of radiation to which the individual was exposed, the energy of the radiation and the area of the body to which the dose was delivered, among others (Thompson, 2001).

Initial exposure to small doses of radiations is known to condition the cells to adaptive response. It enhance DNA repair ability, produce protective proteins to minimize the indirect damaging effect of subsequent high doses of radiations (Cai, 1999), stimulate proliferation as well as immune response (UNSCEAR, 1994) and induce delay in the passage of cells through the cell cycle (Filippovich et al., 1998).

The induction of the adaptive response appears to be influenced by several factors, including the quality of radiation, the time interval between adaptation and challenge doses, the stage of the cell-cycle at which the adaptation dose was delivered, the dose and dose rate used for adaptation and challenge, and the number of adaptation doses used (Bai and Chen, 1993). Furthermore, once induced, the adaptive response was shown to persist in human blood lymphocytes for at least three cell cycles (Coates et al., 2004).

Our results indicated that the overall frequency of aberrant cells was higher in exposed workers (5.5\%) than in controls (3.7\%). These results are in agreement with those reported by Maffei et al. (2004), and the overall frequency of CA (chromosome break and total CA) before exposing to $2 \mathrm{~Gy}$ is significantly higher in exposed group than in the matched controls. The present results for exposed group are in full agreement with the results of previous reports (Kubelka et al., 1992).

We compared induction of cytogenetic radio adaptive response in X-ray occupationally exposed workers to non-exposed controls. We considered X- ray as conditioning doses in radiation workers including $\mathrm{X}$-ray workers. When samples were irradiated to $2 \mathrm{~Gy}$, it was found that the frequency of aberrant cells for X-ray workers 12.7 was lower than exposed control (16.4). Most of the chromosome and chromatid type aberrations decreased in X-ray workers than exposed controls. We scored 12 and 13 polypoidy metaphases in X -ray worker and exposed control, respectively.

In this experiment, the percentages of dicentrics showed that there are no significant changes between controls and exposed workers. Absence of dicentrics 
recorded in the present study or low frequency of dicentrics recorded by many authors (Cardoso et al., 2001 and Maffei et al., 2004) may be due to the low levels of ionizing radiation experienced by the workers (Barquinero et al., 1993).

The present results showed that irradiation of samples resulted in significant difference in the frequency of chromosome break and chromatid fragment (3.3\% and $2.1 \%$, respectively) for X-ray workers when compared with control $(4.7 \%$ and $3.1 \%)$, respectively. Results also showed that the frequency of total CA (10.4\%) and total chromatid aberrations (3.2\%) were significantly lower than exposed controls (13.9\% and $4.7 \%$, respectively). These results are in agreement with previous reports of (Mitchell and Boreham, 2000 and Mozdarani and samavat, 1996).

At low doses, the body's natural repair mechanisms usually perfectly repair any damage incurred (Thompson, 2001). Many of induced DNA lesions are successfully repaired from a few $\min (4-15 \mathrm{~min}$ ) (Tice, 1995) to a couple of $\mathrm{h}$ (2-3 h) (Singh et al., 1988) after exposure. Chromosome and chromatid breaks arise from double strand breaks that have been incompletely repaired or unrepaired. The repair of double strand breaks can also produce double fragments, giving rise to polycentric chromosomes or centric ring chromosomes (Pfeiffer et al., 2000) which are visible on metaphase preparations.

In this test, we observed also increase in the values of the total number of $\mathrm{MN}$ in the exposed group before exposure to $2 \mathrm{~Gy}(176 \mathrm{MN})$ scored in (167 binucleated cell) compared with (130 MN) scored in (123 binucleated cell) in the control group. The probability values of differences between means of binucleated cells with one $\mathrm{MN}$, and the total number of $\mathrm{MN}$ were higher significantly in the exposed group than control. Our observations are in agreement with the studies of Joseph et al. (2004).

The results obtained by Thomas et al. (2003) validate the use of NBP frequency in binucleated cells as a biomarker of DNA damage and chromosome rearrangement. So, we use the measurement of NPB to evaluate in vivo radiation exposure of occupational or medical exposed individuals. Two folds difference in NPB for X-ray workers before exposure to $2 \mathrm{~Gy}$ as compared with control group.

Egypt. J. Rad. Sci. Applic., Vol. 27, No. 1-2 (2014) 
We observed that after irradiation the values of total number of the MN in the X-ray workers (344 MN) scored in (313 Binucleated cell) whereas, in the control group were ( $416 \mathrm{MN}$ ) scored in (384 binucleated cell). Our results also showed that the frequency of cells with one $\mathrm{MN}$ and total number of $\mathrm{MN}$ for $\mathrm{X}$ ray workers (28.6 and 34.3 respectively) were significantly lower than nonexposed individuals $(35.6,41.6$ respectively).This observation is in agreement with previous findings of other authors, who found that the mean $\mathrm{MN} / \mathrm{cell}$ for radiation workers' lymphocytes after 1 and 2 Gy irradiation was significantly lower than the control group (Gourabi and Mozdarani, 1998).

The results also showed that the frequency of NPB for X-ray workers (2.0\%) were significantly lower than exposed individuals (3.6\%). The inclusion of NPB may also enhance the capacity of the cytokinesis block MN assay to identify those individuals with higher DNA repair capacity after radiation.

The present study has been assessed the cytogenetic changes as manifested by 2 techniques, the rate of $\mathrm{CA}$, and $\mathrm{MN}$ in peripheral blood lymphocytes, which are considered to be ideal systems for studying the chromosome changes of human subjects occupationally exposed to X-ray. We depend mainly on wide range of cell counts; genetic pool for each individual due to the limited size of the samples. In fact, previous evidence has been obtained that the cellular response of people exposed to low dose radiation is surprisingly stronger than would be expected in view of the amount of energy deposed and/or the fraction of cells actually traversed (Mothersill and Seymour, 2004).

In the present investigation, before exposure to 2 Gy $\gamma$-radiation, IL- $1 \beta$ concentration in examined X-ray medicine workers showed slightly higher significance than that in the control group. However, their levels remained within normal limits. This slight increase in IL-1 $\beta$ recorded in our study demonstrates the induction of limited inflammation under the effect of occupational exposure to ionizing radiation. Our results are in line with earlier studies of Klusiniski et al. $\left(2006^{\mathrm{a}}\right)$.

As well, previous studies showed that serum concentration of C-reactive protein (CRP), interleukin-1 $\beta$, TNF- $\alpha$, IL-6 showed only slightly higher increase in X-ray department workers compared with control group (Hrycek et al.,2002 and Klusiniski et al., 2005\&2006 ).

Egypt. J. Rad. Sci. Applic., Vol. 27, No. 1-2 (2014) 
The investigation revealed that 2 Gy $\gamma$-irradiation (challenge dose) caused higher significant increase in the concentration of IL-1 $\beta$ in exposed group (5.1 folds) than that of the corresponding groups before irradiation. Whereas, there are higher increment difference observed for control group after irradiation as compared to the same group before irradiation ( 8.3 folds). The present results are in agreement with Linard et al. (2004) and O'Brien-Ladner et al. (1993). From the present results, we can suggest that IL-1 $\beta$ in occupationally exposed workers may have a protective role against exposure to the challenge dose.

Cytokine-induced priming leads to increase NO production in the macrophage, so it is not surprising that radiation induced priming has the same effect. As well, the present results revealed that the NO concentration in examined X-ray medicine workers showed higher significance than that in the control group. These results are in broad agreement with previous studies of Han et al. (2010).

The investigation revealed that 2 Gy irradiation caused higher increase in the concentration of $\mathrm{NO}$ in exposed group (1.2 folds) than that of the corresponding group before irradiation. Whereas, there was higher increment observed for control group after exposure to in vitro $2 \mathrm{~Gy} \gamma$-ray as compared to the same group before irradiation. These results are consistent with Ibuki et al. (2003). Other authors reported that NO modulates cell radiosensitivity (Verovski et al., 1996), and ionizing radiation increases NO production by inducing NO synthesis (NOS) expression and stimulating constitutive NOS (Leach et al., 2002). Matsumoto et al. (2004) and Shankar et al. (2006) suggested that reactive nitrogen species (RNS), particularly NO secreted from irradiated cells may initiate a signaling pathway to induce the radioadaptive response. Matsumoto et al. (2007) also stated that radio-adaptive responses have been observed using various end points, such as CA, mutations, and clonogenic survival. They found that radioresistance observed in the radioadaptive response can be induced by $\mathrm{NO}$ at extremely low concentrations, which are endogenously generated after exposure to radiation.

\section{Conclusion}

The present results pointed to the presence of cytogenetic adaptive response in medicinal workers occupationally exposed to low dose of X-ray. In addition, the results explained that NO radicals and IL $-1 \beta$ have a role in the induction of radio-resistance due to in vivo exposure that may intermediate this radiation exposure.

Egypt. J. Rad. Sci. Applic., Vol. 27, No. 1-2 (2014) 


\section{Acknowledgment}

The authors greatly appreciate Dr. M. H. Shabon, Radiation Safety Dept., Nuclear \& Radiological Regulatory Authority (NRRA) for help in blood sampling.

\section{References}

AAMP (1995) Radiation information for hospital personnel. American Association Physics Medicine Report No. 53.

Bai, Y. and Chen, D. (1993) Accumulative effect of two low doses of irradiation in inducing an adaptive response in human lymphocytes. Mutat. Res., 302, 191.

Barquinero, J. F., Barrios, L., Caballin, M. R., Miro, R., Ribas, M., Subias, A. and Egozcue, J. (1993) Cytogenetic analysis of lymphocytes from hospital workers occupationally exposed to low level of ionizing radiation. Mutat Res., 286, 275.

Brune, B. (2003) Nitric oxide: NO apoptosis or turning it on? Cell Death Differ., 10, 864.

Cai, L. (1999) Research on the adaptive response induced by low dose radiation: Where have we been and where should we go? BELLE News letter., 7,1.

Cardoso, R. S., Takahashi-Hyodo, S., Ghilardi-Neto, P. T., Sakamoto-Hojo, E. T. and Peitil, Jr, P. (2001) Evaluation of chromosomal aberrations, micronuclei, and sister-chromatid exchanges in hospital workers chronically exposed to ionizing radiation. Teratog. Carcinog. Mutagen., 21, 431.

Coates, P. J., Lorimore, S. A. and Wright, E. G. (2004) Damaging and protective cell signalling in the untargeted effects of ionizing radiation. Mutat Res., 568, 5.

Fenech, M. (1993) The cytokinesis-block micronucleus technique: A detailed description of the method and its application to genotoxicity studies in human populations, Mutat. Res., 285, 35 .

Fenech, M. (2000) The in vitro micronucleus technique. Mutat. Res., 455, 81.

Fenech, M. and Morley, A. A. $\left(\mathbf{1 9 8 5}^{\mathrm{a}}\right)$ Measurement of micronuclei in lymphocytes, Mutat. Res., 147, 29.

Filippovich, J. V., Sorokina, N. I., Robillard, N., Lisbona, A. and Chatala, J. F. (1998) Radiation-induced apoptosis in human tumour cell lines: adaptive response and split-dose effect. Int. J. Cancer, 77, 76.

Goldberg, Z., Schwietert, C. W., Lehnert, B., Stern, R. and Nami, I. (2004) Effects of low-dose ionizing radiation on gene expression in human skin biopsies. Int. J. Radiat. Oncol. Biol. Phys., 58, 567.

Gourabi, H. and Mozdarani, H. (1998) A cytokinesis blocked micronucleus study of the radioadaptive response of lymphocytes of individuals occupationally exposed to chronic doses of ionizing radiation. Mutagenesis, 13, 475. 
Han, W., Chen, S., Yu, K. N. and Wu, L. (2010) Nitric oxide mediated DNA double strand breaks induced in proliferating bystander cells after $\alpha$-particle irradiation. Mutat. Res., 684, 81 .

Hrycek, A., Czerneck-Micinska, A., Klucinski, P. and Badowski, R. (2002) Peripheral blood lymphocytes and selected serum interleukins in workers operating x-ray equipment. Toxicol. Lett., 132, 101.

IAEA (2001) Cytogenetic analysis for radiation dose assessment. In: International Atomic Agency Technical Report Series, 405. IAEA, Vienna, p. 138.

Ibuki, Y., Mizuno, S. and Goto, R. (2003) $\gamma$-Irradiation-induced DNA damage enhances NO production via NF-kB activation in RAW264.7 cells. Biochim. Biophys. Acta, 1593, 159.

ICRP (1990) Recommendations of the International Commission on Radiation Protection. Tarrytown, New York: Elsevier Science, 21, 1.

Joseph, L. J., Patwardhan, U. P., Aban, M. and Samuel, A. M. (2004) Frequency of micronuclei in peripheral blood lymphocytes from subjects occupationally exposed to low levels of ionizing radiation. Mutat. Res., 564, 83.

Klucinski, P., Maoeluch, E., Wiechuła, B., Hrycek, A., Mazur, B. and Kaufman, J. $\left(\mathbf{2 0 0 6}^{\mathbf{b}}\right)$ Serum concentrations of tumor necrosis factor- $\alpha$ and its soluble receptor TNFR1 and TNFR2 in workers of x-ray departments. Ann. Acd. Med. Siles., 60, 308.

Klucinski, P., Mazur, B., Kaufman, J., Hrycek, A., Cieoelik, P. and Martirosian, G. (2005) Assement of blood serum immunoglobulin an C-reactive protein concentrations in workers of x-ray diagnostics units. Int. J. Occup. Med. Environ. Health, 18, 327.

Kłuciński, P., Mazur, B., Wiechuła, B., Maoeluch, E., Kaufman, J., Hrycek, A., Cieslik, P. and Martirosian, G. (2006 $\left.{ }^{\mathrm{a}}\right)$ Evaluation of cellular isoform of prion protein expression on the surface peripheral blood monocytes and serum concentrations of interleukin- $1 \beta$ and interleukin- $1 \beta$ receptor antagonist in workers operating x-ray equipment . Diagn. Lab., 42, 369.

Kubelka, D., Garaj-Vrhovac, V. and Horvat, D. (1992) Chromosomal aberration in persons occupationally exposed to annual $\mathrm{X}$-irradiation doses lower than 25 mSv. J. Radiat. Protect., 12, 33.

Laiakis E. C, Baulch J. E and Morgan W. F. (2007) Cytokine and chemokine responses after exposure to ionizing radiation: Implications for the astronauts. Advanc. Space Res., 39, 1019.

Leach, J. K., Black, S. M., Schmidt-Ullrich, R. K. and Mikkelsen, R. B. (2002) Activation of constitutive nitric-oxide synthase is an early signalling event induced by ionizing radiation. J. Biol. Chem., 277, 15400.

Li, C. Q. and Wogan, G. N. (2005) Nitric oxide as a modulator of apoptosis. Cancer Lett., 226, 1.

Egypt. J. Rad. Sci. Applic., Vol. 27, No. 1-2 (2014) 
Linard, C., Marquette, C., Mathieu, J., Pennequin, A., Clarencon, D. and Mathe, D. (2004) Acute induction of inflammatory cytokine expression after gammairradiation in the rat: effect of an NF-kappaB inhibitor. Int. J. Radiat. Oncol. Biol. Phys., 58, 427.

Maffei, F., Angelini, S., Forti, G. C., Violante F. S., Lodi, V., Mattioli, S. and Hrelia, P. (2004) Spectrum of chromosomal aberrations in peripheral lymphocytes of hospital workers occupationally exposed to low doses of ionizing radiation. Mutat. Res., 547, 91.

Matsumoto, H., Hamada, N., Takahashi, A., Kobayashi, Y. and Onishi, T. (2007) Vanguards of paradigm shift in radiation biology: Radiation-induced adaptive and bystander responses. J. Radiat. Res., 48, 97.

Matsumoto, H., Takahashi, A. and Ohnishi, T. (2004) Radiation-induced adaptive responses and bystander effects. Biol. Sci. Space, 18, 247.

Miranda, K. M., Espey, M. G. and Wink, D. A. (2001) A rapid simple spectrophotometric method for simultaneous detection of nitrate and nitrite. Nitric Oxide: Biology and Chemistry, 5, 62.

Mitchell, R. E. J. and Boreham, D. R. (2000) Radiationprotection in the world of modern radiobiology: Time for a new approach. In: Proceedings of the 10th international congress of the international radiation protection association: IRPA. Hiroshima, Japan, Plenary Session, p. 1-2.

Mothersill, C. and Seymour, C. (2004) Radiation-induced bystander effects and adaptive responses-the Yin and Yang of low dose radiobiology? Mutat. Res., $\mathbf{5 6 8}, 121$.

Mozdarani, H. and Samavat, H. (1996) Cytogenetic biomonitoring of 65 radiology technologists occupationally exposed to chronic doses of $\mathrm{X}$-irradiation in Iran. Med. J. Iran, 10, 43.

Neta, R., Oppenheim, J. J., Schreiber, R. D., Chizzonite, R., Ledney, G. D. and MacVittie, T. J. (1991) Role of cytokines (interleukin 1, tumor necrosis factor, and transforming growth factor beta) in natural and lipopolysaccharide- enhanced radioresistance. J. Exp. Med., 173, 1177.

O'Brien-Ladner, A., Nelson, M. E., Kimler, B. F. and Wesselius, L. J. (1993) Release of interleukin-1 by human alveolar macrophages after in vitro irradiation. Radiat. Res., 136, 37.

Pfeiffer, P., Goedecke, W., Obe, G. (2000) Mechanisms of DNA double strand break repair and their potential to induce chromosomal aberrations. Mutagenesis, 15, 289.

Prasad, K. N., Cole, W. C. and Haase, G. M. (2004) Radiation protection in humans: extending the concept of as low as reasonably achievable (ALARA) from dose to biological damage. Br. J. Radiol., 77, 97. 
Ropolo, M., Balia, C., Roggieri, P., Lodi, V., Nucci, M. C., Violante, F. S., Silingardi, P., Colacci, A. and Bolognesi, C. (2012) The micronucleus assay as a biological dosimeter in hospital workers exposed to low doses of ionizing radiation. Mutat. Res., 747, 7.

Shankar, B., Pandey, R. and Sainis, K. (2006) Radiation-induced bystander effects and adaptive response in murine lymphocytes. Int. J. Radiat. Biol., 82, 537.

Singh, N. P., Mc Coy, M. T., Tice, R. R. and Schneider, E. L. (1988) A simple technique for quantitation of low levels of DNA damage in individual cells. Exp. Cell Res., 175, 184.

Snedecor, W. G. and Cochron, G. W. (1980) Statistical methods. 7th edition, Iowa State University Press, Ames, Iowa.

Thomas, P., Umegaki, K. and Fenech, M. (2003) Nucleoplasmic bridges are a sensitive measure of chromosome rearrangement in the cytokinesis-block micronucleus assay. Mutagenesis, 18, 187.

Thompson, M. A. (2001) Maintaining a proper perspective of risk associated with radiation exposure. J. Nucl. Med. Technol., 29, 137.

Tice, R. R. (1995) The single cell gel/ comet assay: a microgel electrophoretic technique for the detection of DNA damage and repair in individual cells. In: Phillips D.H, Vennit S, editors. Environm. Mutagen., 315, 39.

UNSCEAR (1994) Sources and Effects of Ionizing Radiations, Report, United Nations, New York.

Verovski, V. N., Van den Berge, D. L., Soete, G. A., Bols, B. L. and Storm, G. A. (1996) Intrinsic radiosensitivity of human pancreatic tumour cells and the radiosensitising potency of the nitric oxide donor sodium nitroprusside. $\mathrm{Br}$. $J$. Cancer., 74, 1734.

Weiss, J. F. and Landauer, M. R. (2000) Radioprotection by antioxidants. Ann. N. Y. Acad. Sci., 899, 44.

Wolff, S., Wiencke, J. K., Afzal, V., Youngblom J. and Cortes. F. (1989) The adaptive response of human lymphocytes to very low doses of ionizing radiation: a case of induced chromosomal repair with the induction of specific proteins. In: Baverstock, K.F. and StatherJ.W. (eds), Low Dose Radiation: Biological Bases of Risk Assessment. Taylor \& Francis, London, $U K .$, p. 446.

Xu, W., Liu, L. Z. and Loizidou, M. (2002) The role of nitric oxide in cancer. Cell Res., 12, 311.

(Received: 11/12/2013;

accepted: 18/02/2014)

Egypt. J. Rad. Sci. Applic., Vol. 27, No. 1-2 (2014) 


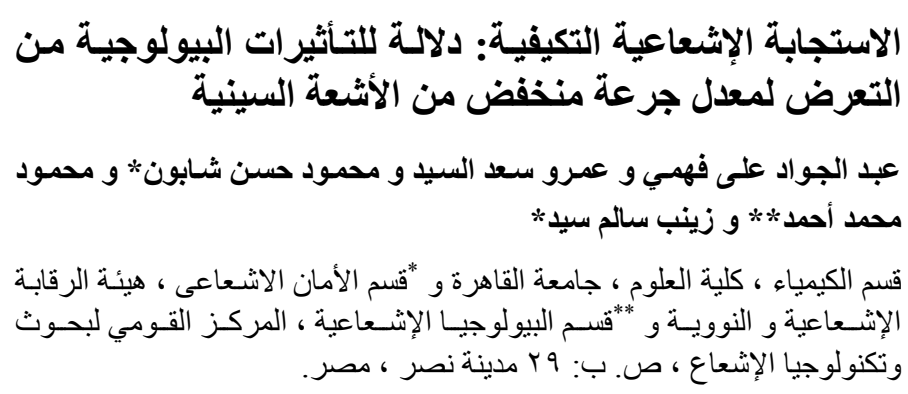

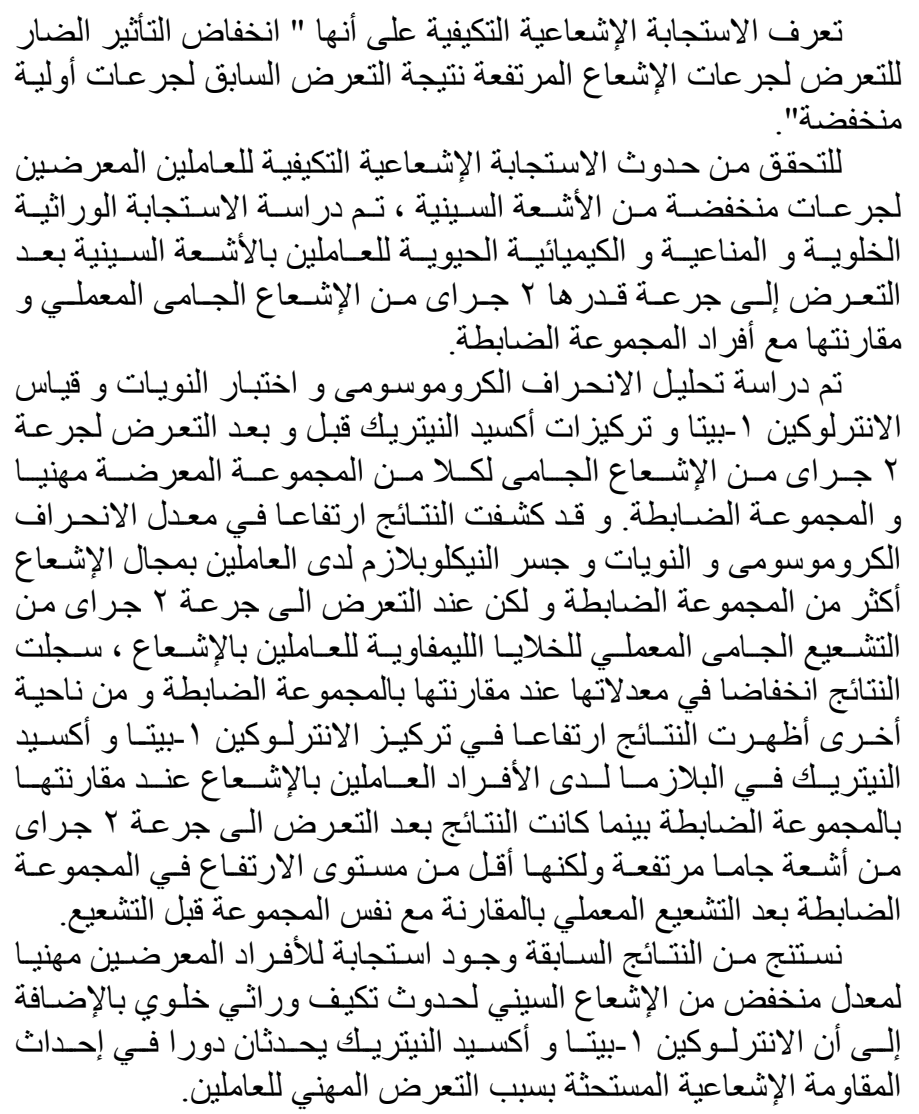

Egypt. J. Rad. Sci. Applic., Vol. 27, No. 1-2 (2014) 